\title{
VAI ANO DROŠĪBAS PADOMEI IR SAISTOŠAS STARPTAUTISKĀS TIESİBAS?
}

\section{IS THE UN SECURITY COUNCIL BOUND BY INTERNATIONAL LAW?}

\author{
Ieva Mil,ūna, Mg. soc. sc., LL.M
}

Rīgas Juridiskās augstskolas lektore

\section{Summary}

This article explores the topic whether the UN Security Council is bound by international law. The author examines the founding documents of the UN as well as the UN Security Council's role in resolving international situations and disputes. The author's main argument is that the function of the UN Security Council to maintain international peace and security cannot be fulfilled by not being bound by international law. The author derives it from the UN Charter interpretation, the International Court of Justice cases and legal doctrine. The author also claims that by delegating their powers to the UN Security Council, the UN Member States have made the political organ bound by their international law obligations.

Atslēgvārdi: ANO Drošības padome, starptautiskās tiesības, starptautiskais miers un drošība, ANO Statūti, jus cogens

Keywords: UN Security Council, international law, international peace and security, UN Charter, jus cogens

\section{Ievads}

Apvienoto Nāciju Organizācijas (turpmāk - ANO) dibināšana iezīmē nozīmīgu posmu starptautisko tiesību vēsturē. Līdz ar ANO Statūtu pieñemšanu tika aizliegta bruņota spēka lietošana jeb karš kā strīdu risināšanas līdzeklis starptautiskajās attiecībās. Kā galvenais ANO orgāns, kuram tika piešķirta kompetence regulēt starptautisko mieru un drošību, tika izveidota ANO Drošíbas padome. Tā kā ANO Drošìbas padomes sastāvā ir tikai 15 valstis jeb locekles (piecas pastāvīgās locekles un 10 nepastāvīgās locekles) un pastāvīgajām loceklēm jebkura jautājuma izšksiršanā ir veto tiesības, šì orgāna lēmumi lielā mērā ir politiski.

Autores mērķis ir noskaidrot, vai ANO Drošỉbas padomei kā vienam no galvenajiem ANO politiskajiem orgāniem ir saistošas starptautiskās tiesības. Lai to izzinātu, autore apskatīs ANO kā organizācijas dibināšanas mērķus un to, kā šajā sakarībā ir interpretējami ANO Statūti, kā arī analizēs, kāda ir ANO Drošības padomes loma starptautisko strīdu un situāciju risināšanā un kā ANO Drošỉbas padomes funkcija uzturēt starptautisko mieru un drošibu padara 
starptautiskās tiesības tai saistošas. Noslēgumā autore apskatīs ANO dalībvalstu pienākumu ietekmi uz ANO Drošības padomes darbību.

\section{Apvienoto Nāciju Organizācijas dibināšanas mērḳi}

ANO Drošības padomei kā vienam no ANO politiskajiem orgāniem, kas dibināts saskaṇā ar ANO Statūtiem, ir saistošs tā konstituējošais dokuments, proti, ANO Statūti. Šis dokuments noteic šì politiskā orgāna darbību. ANO Statūtu 24. panta pirmā daḷa paredz, ka ANO dalībvalstis piešķir ANO Drošìbas padomei primāro atbildību par starptautiskā miera un drošības uzturēšanu. Taču ANO Statūtu 24. panta otrā daḷa nodibina to, ka, pildot savu pienākumu uzturēt starptautisko mieru un drošību, ANO Drošības padomei ir jārīkojas saskaṇā ar ANO mērķiem un principiem. Šajā sakarībā aktuāls ir jautājums, vai ANO mērķi un principi (kas noteikti ANO Statūtu 1. un 2. pantā) paredz politiskajam orgānam pienākumu rīkoties saskaṇā ar starptautiskajām tiesībām?

ANO mērḳi, kas definēti ANO Statūtu 1. panta pirmajā daḷā, noteic, ka starptautiskā miera un drošības uzturēšanas vārdā ANO ir jāsekmē starptautisko strīdu un situāciju, kas var novest pie miera pārkāpšanas, izlīdzināšana un atrisināšana mierīgā ceḷā un saskaṇā ar taisnīguma principiem un starptautiskajām tiesībām. Šajā panta daḷā ANO Statūti tieši atsaucas uz starptautiskajām tiesībām. ANO Statūtu 1. panta trešà daļa atsaucas uz nepieciešamību sekmēt cilvēktiesību ievērošanu. Savukārt pati ANO preambula runā par cilvēktiesību nozìmību, līgumu un citu starptautisko tiesību avotu ievērošanu. Autore uzskata, ka šie ANO pienākumi rīkoties saskaṇā ar starptautiskajām tiesībām ir pilnībā attiecināmi uz ANO Drošības padomi, jo to ir paredzējuši ANO Statūtu dibinātāji.

ANO dibināšanas laikā Sanfrancisko konferencē ir izteikts viedoklis, ka ANO ir jādarbojas ne tikai kā politiskai organizācijai, bet tai ir jābūt saistošām starptautiskajām tiesībām. ${ }^{1}$ Tas noveda pie ANO Statūtu preambulas, kā arī 1. un 2. panta papildināšanas ar atsaucēm uz starptautiskajām tiesībām. ${ }^{2}$ Vèl jo vairāk, tā bija premisa, uz kuras tika balstīti 1944. gada Dumbartonas Ozolu priekšlikumi, ${ }^{3}$ kas ir ANO Statūtu sākotnējais dibināšanas dokuments, proti, ka starptautiskā miera un drošỉbas uzturēšanas sistēmas efektivitāte būtu jāveicina, ietverot dokumenta tekstā organizācijas vadības mērķus un principus. ${ }^{4}$ Savukārt šie mērḳi un principi paredz, ka ANO ir jārīkojas saskaṇā ar taisnīguma principiem un starptautiskajām tiesībām.

Kà nozìmīgu instrumentu autore vēlas minèt 1942. gadā pieṇemto dokumentu "Starptautisko tiesību nākotne. Postulāti, principi un priekšlikumi", kuru izstrādājuši 200 prominenti amerikāṇu un kanādiešu eksperti. Šis dokuments, kas atspoguḷo daḷu no tālaika starptautisko tiesību doktrīnas, atklāj

1 Wolfrum R. Preamble. In: Simma B. et al. (eds.). The Charter of the United Nations. A Commentary. Vol. I. Oxford: Oxford University Press, 2002, p. 36.

2 Ibid.

3 Goodrich L. M., Hambro E. Charter of the United Nations. Commentary and Documents. Boston: World Peace Foundation, 1946, p. 308.

4 Wolfrum R. Purposes and Principles. In: Simma B. 2002, pp. 39-40.

5 The International Law of the Future. Postulates, Principles and Proposals. American Journal of International Law, 1944, Vol. 38, Sup. 41. 
būtisku aspektu par to, kādu lomu starptautiskās tiesības iennems jaunajā pasaules kārtībā. Lai arī dokuments uzsver nevis galveno jaunās pasaules organizācijas mērḳi - starptautiskā miera un drošības uzturēšanu -, bet gan tautu kopējo interešu aizsardzību un attīstỉbu (1. postulāts), tas atsaucas uz atziṇu, ka "[v]alstu kopienas tiesības ir starptautiskās tiesibas" (2. postulāts) un "katras valsts darbība attiecībās ar citām valstīm un valstu kopienu ir pakḷauta starptautiskajām tiesībām" (3. postulāts). ${ }^{6}$ Autore uzskata: lai arī šis dokuments nenosaka konkrētu normatīvu standartu ANO Drošibas padomei, tas parāda, ka stingrs tālaika tiesību doktrīnas pamatprincips ir bijis tāds, lai jauno pasaules valstu kopienu vadītu starptautiskās tiesības. Tādējādi tas papildina ANO Statūtu pamatmērḳu pieṇemšanas kontekstu doktrinālā aspektā.

\section{Starptautisko strīdu un situāciju risināšana saskaṇā ar starptautiskajām tiesībām}

Autore uzskata, ka ANO Drošỉbas padomes funkcija starptautiskā miera un drošibas uzturēšanā satur starptautisko strīdu un situāciju izlīdzināšanu vai atrisināšanu, kā tas ir formulēts ANO Statūtu 1. panta pirmajā dạ̣ā. Un, tā kā ANO Statūtu mērķi un principi, kas definēti to 1. un 2. pantā, ietver prasību strīdus un situācijas risināt saskaṇā ar starptautiskajām tiesībām, ANO Drošības padomei ir pienākums savā darbībā ievērot starptautiskās tiesỉbas. Minēto atbalsta arī ANO Statūtu komentētājs Rīdigers Volfrums (Rüdiger Wolfrum), kurš uzskata, ka ANO mērḳi, kas noteikti ANO Statūtu 1. pantā, ir juridiski saistoši. ${ }^{7}$

Autore uzskata, ka ANO Drošības padomei ir saistošas starptautiskās tiesības, kad tā darbojas gan saskaņā ar ANO Statūtu VI nodaḷu (kas paredz rekomendējošus pasākumus), gan arī VII nodaļu (kas paredz piespiedu pasākumus).

Lai arī ANO Statūtu 1. panta pirmā daḷa atsaucas uz tādiem terminiem kā "strīdi" un "situācijas", ANO Statūtu VI nodal̨a par miermīlīgu strīdu risināšanu nediferencē starptautiskos "strīdus" un "situācijas". Arī tiesību doktrīnā ir apstiprināts viedoklis, ka dažos aspektos nošķīrums starp strīdu un situāciju ir gaistošs un dažādu iemeslu dēl pilnīgi nenozīmīgs. ${ }^{8}$ ANO Drošìbas padomes funkcija uzturēt starptautisko mieru un drošību padara ANO Statūtus un vispārējās starptautiskās tiesības saistošas politiskajam orgānam, kad tas darbojas, pamatojoties uz ANO Statūtu VI nodalı.

Vēsturiski Sanfrancisko konferences laikā I/1 komitejā un I Komisijā tika ierosināts taisnīguma garantijas principu (angḷu val. - principle of guarantee of justice) padarīt par miera nodrošinājumu. Tika izteikts priekšlikums ANO Statūtu 1. panta pirmajā dạ̣ā vārdus "saskañā ar taisnīguma principiem un starptautiskajām tiesībām" ietvert tieši pēc vārdiem "uzturēt starptautisko mieru un drošỉbu". 9 Tādējādi ANO dibinātāju nodoms ir bijis padarīt starptautiskā miera un drošìbas uzturēšanu efektîvu tieši tādā veidā, ka tai būtu jāsaskan ar starptautiskajām tiesībām.

\footnotetext{
6 The International Law of the Future. Postulates, Principles and Proposals. American Journal of International Law, 1944, Vol. 38, Sup. 41.

7 Wolfrum R. Purposes and Principles. In: Simma B. 2002, pp. 39-40.

8 Conforti B. The Law and Practice of the United Nations. The Hague, London, Boston: Kluwer Law International, 1996, p. 79.

9 Goodrich L. M., Hambro E. 1946, p. 59.
} 
Attiecībā uz ANO Drošỉbas padomes darbību saskaṇā ar ANO Statūtu VII nodaḷu dažādu autoru viedokḷi dalās. Vieni uzskata, ka ANO Statūtu 1. panta pirmā daḷa nav piemērojama kolektīvās drošības pasākumiem saskaṇā ar ANO Statūtu VII nodalılu, ${ }^{10}$ taču citi pauž viedokli, ka ANO Statūtu 1. panta pirmā daḷa pat sašaurina attiecīgo orgānu rīcības brīvības pilnvaras un ANO Statūtu 1. panta pirmā dal̦a ir piemērojama ANO Statūtu VII nodal̦as pasākumiem. ${ }^{11}$ Autore uzskata, ka ANO Statūtu 1. panta pirmā daḷa tieši atsaucas uz kolektīvu pasākumu pieņemšanu, lai novērstu miera apdraudējumu, apturētu agresijas aktus un citus miera pārkāpumus. Šie pasākumi ir tāda rakstura, kas neapšaubāmi prasa ne tikai ANO Statūtu VI nodaļas, bet arī VII nodaḷas iesaisti. Autore uzskata, ka visi starptautiskie strīdi un situācijas atsaucas uz bīstamību, ka tie var novest pie miera pārkāpuma tādā veidā, kā tas ir formulēts ANO Statūtu 1. panta pirmajā daḷā. Turklāt ANO Drošỉbas institucionālā iesaiste ir paredzēta darbībām saskaṇā gan ar ANO Statūtu VI, gan VII nodaḷu. Tādējādi ANO Drošības padomi saista starptautiskās tiesības, kas ANO Statūtu 1. panta pirmajā daḷā ir norādītas kā instrumentālas starptautiskā miera un drošỉbas uzturēšanā un risināšanā.

\section{Apvienoto Nāciju Organizācijas Drošības padomes funkcija uzturēt starptautisko mieru un drošîbu}

ANO Drošibas padomei ir saistošas starptautiskās tiesības, kas definētas ANO Statūtu 1. panta pirmajā dal̦ā sakarā ar tās funkciju uzturēt starptautisko mieru un drošìbu. Pienākums atrisināt starptautiskos strīdus vai situācijas, kuras var novest pie miera pārkāpuma, saskaņā ar starptautiskajām tiesībām ir adresēts ANO kā organizācijai. Tas ietver arī ANO Drošības padomi. Autore uzskata, ka pienākums darboties saskaṇā ar starptautiskajām tiesībām ir saistošs politiskajam orgānam saistībā ar tā primāro atbildību uzturēt starptautisko mieru un drošību. To atzīst arī profesore Mērija Elena O’Konela (Mary Ellen O’Connell). ${ }^{12}$ Papildus tam arī ANO komentētāji atsaucas uz starptautiskā miera un drošības uzturēšanas funkciju kā atslēgvārdu, secinot, ka pienākumi, kas izriet no starptautiskā miera un drošības uzturēšanas, ir jāinterpretē saskaņā ar ANO Statūtu 1. panta pirmo un otro dal̦u, 2. panta trešo, ceturto, piekto un sesto dal̦u, kā arī ANO Statūtu IV, VI un VII nodal̦u. ${ }^{13}$ Tādējādi autore secina, ka bez starptautisko tiesību piemērošanas un īstenošanas nav iespējama ANO Drošibas padomes funkciju izpilde.

\footnotetext{
${ }^{10}$ Frowein J., Krisch N. Chapter VII. Action with respect to Threats to the Peace, Breaches of the Peace, and Acts of Aggression. In: Simma B. 2002, p. 705.

11 Wolfrum R. Purposes and Principles. In: Simma B. 2002, p. 43; Lamb S. Legal Limits to United Nations Security Council Powers. In: Goodwin-Gill G. S., Talmon S. (eds.). The Reality of International Law. Essays in Honour of Ian Brownlie. Oxford: Clarendon Press, 1999, p. 367.

12 O'Connell M. E. The United Nations Security Council and the Authorization of Force: Renewing the Council Through Law Reform. In: Blokker N., Shrijver N. (eds.). The Security Council and the Use of Force. Leiden, Boston: Martinus Nijhoff Publishers, 2005, p. 48.

13 Wolfrum R. Preamble. In: Simma B. 2002, pp. 36-37.
} 
Nevienam no ANO orgāniem nav tik plašas politiskās pilnvaras uzturēt starptautisko mieru un drošỉbu kā ANO Drošības padomei. ${ }^{14}$ Vēl jo vairāk, ANO Statūtu VI daļas, it īpaši 34. panta, redakcija ņem vērā faktu, ka jebkurš starptautiskais strīds vai situācija var nonākt līdz miera apdraudējumam, miera pārkāpumam vai agresijas aktam, kā tie ir definēti ANO Statūtu VII nodaḷas 39. pantā. Arī Filipe Sendss (Philippe Sands) un Pjērs Klains (Pierre Klein) to apstiprina, norādot, ka ANO Drošības padomes primārā funkcija uzturēt starptautisko mieru un drošỉbu ir īstenojama ar diviem lìdzekḷiem - starptautisko strīdu miermīlīgu risināšanu un piespiedu īstenošanas darbību (angḷu val. enforcement action), ${ }^{15}$ kas saskan ar ANO Statūtu VI un VII nodaḷas nošķīrumu.

Pat ja strīdu risināšana nav tas pats, kas miera piespiedu īstenošana, ${ }^{16}$ tas neatņem ANO Statūtu 24. panta otrās daḷas saistošo raksturu, ka ANO Drošìbas padomei, pildot tās funkcijas, ir jādarbojas saskaṇā ar ANO mērḳiem un principiem, kas paredz darbību saskaṇā ar starptautiskajām tiesībām. Arī ANO Starptautiskās tiesas konsultatīvais atzinums Reparāciju lietā atbalsta viedokli, ka ANO Drošibas padomes funkcija starptautiskā miera un drošības nodrošināšanā kā pašas organizācijas primārā funkcija padara ANO Statūtus un vispārējās starptautiskās tiesības ANO Drošības padomei saistošus. ${ }^{17}$

\section{Apvienoto Nāciju Organizācijas dalībvalstu pienākumu ietekme uz Apvienoto Nāciju Organizācijas Drošỉbas padomi}

ANO Statūtu 2. pants nostiprina ANO principus. Šie principi paši par sevi neatsaucas uz konkrētu ANO un to dalībvalstu pienākumu ievērot starptautiskās tiesības. Taču ievada klauzula ANO Statūtu 2. pantam tieši nostiprina to, ka ne tikai ANO, bet arī tās dalībvalstīm, sekojot mērḳiem, kas noteikti ANO Statūtu 1. pantā, ir jādarbojas saskaṇā ar principiem, kuri uzskaitīti ANO Statūtu 2. pantā. ANO Statūtu komentētājiem ir viedoklis, ka tas uzliek pienākumus ANO dalībvalstīm. ${ }^{18}$

Autore uzskata, ka sakarā ar ANO Statūtu 24. panta pirmo dalu, kura noteic, ka ANO Drošības padome darbojas ANO dalībvalstu vārdā, ANO dalībvalstis ANO Drošības padomei ir delegéejušas savu kolektīvo varu pār starptautiskā miera un drošības nodrošināšanu ${ }^{19}$ saskaṇā ar starptautiskajām paražu tiesību normām. ANO Statūtu komentētāji gan argumentē, ka ANO Drošỉbas padome iegūst savu varu no ANO Statūtiem, nevis no tās dalībvalstīm. ${ }^{20}$ Tomèr ANO dalībvalstis ir pieṇēmušas ANO Statūtus un tādējādi uzticējušas ANO Drošības

${ }^{14}$ Sk. autores rakstu par šo tēmu: Miluna I. What Does the Uniting for Peace Resolution Mean for the Role of the UN Security Council? American Journal of International Law Unbound, 2014, Vol. 108, pp. 118-122.

15 Sands P., Klein P. Bowett's Law of International Institutions. London: Sweet \& Maxwell, 2001, p. 43.

16 Frowein J., Krisch N. 2002, pp. 706, 721.

17 Conforti B. 1996, p. 13; ANO ST 11.04.1949. konsultatīvais atzinums lietā Reparation for Injuries Suffered in the Service of the United Nations.

18 Randelzhofer A. Article 2. In: Simma B. 2002, p. 64.

19 Sarooshi D. The United Nations and the Development of Collective Security. The Delegation by the UN Security Council of its Chapter VII Powers. Oxford: Clarendon Press, 1999, pp. 25-28; Sands P., Klein P. 2001, pp. 42-43; ANO ST 02.12.1963. spriedums lietā Northern Cameroons (Cameroon v. United Kingdom), tiesneša Sir Gerald Fitzmaurice atsevišķās domas.

${ }^{20}$ Delbrück J. Article 24. In: Simma B. 2002, p. 447. 
padomei varu uzturēt starptautisko mieru un drošibu. Šĩs pilnvaras pašas par sevi neietver pienākumu ievērot ANO Statūtus un starptautiskās tiesības. Tomēr autore uzskata, ka šo pilnvaru īstenošana ietver mērķu un principu ievērošanu, kā tie ir definēti ANO Statūtos.

Vēl jo vairāk, ANO Statūtu 24. panta otrā daḷa noteic, ka ANO Drošības padomei, pildot pienākumu uzturēt starptautisko mieru un drošību, ir jādarbojas saskaṇā ar ANO mērķiem un principiem. Tāds pats pienākums ir uzlikts ANO dalībvalstīm saskaņā ar ANO Statūtu 2. panta trešo dalı. Tādējādi autore secina, ka ANO dalībvalstu pienākums darboties saskaṇā ar ANO mērkiem un principiem ar kolektīvās drošỉbas pilnvaru nodrošināšanu ar delegéěšanu ir uzlikts arī ANO Drošìbas padomei.

ANO Drošības padomei jebkurā gadījumā ir saistošas jus cogens normas, kas ir absolūti aizliegumi starptautiskajās tiesībās un izriet no ANO dalībvalstu pienākumiem. To apliecina ANO Starptautiskās tiesas lieta Lokerbijas lietā. ${ }^{21}$ Jus cogens normu saistošais raksturs attiecībā uz ANO Drošibas padomi izriet no ANO Statūtiem un ANO dalībvalstu starptautisko paražu tiesību pienākumiem, kur gan pati ANO, gan tās dalībvalstu prakse atzīst konkrētas starptautisko tiesību normas (genocīds, verdzības aizliegums, aparteīds, noziegumi pret cilvēci) kā absolūtus aizliegumus starptautiskajās attiecībās, ko sīkāk apliecina ANO Statūtu interpretācija.

\section{Secinājumi}

1. Pienākums ievērot starptautiskās tiesības, kas ir adresēts ANO kā organizācijai tās Statūtu preambulā, kā arī 1. un 2. pantā, ir pilnībā piemērojams ANO Drošibas padomei.

2. Lai pildītu starptautiskā miera un drošỉbas uzturēšanas funkciju, ANO Drošỉbas padomei ir saistoši ANO Statūti un vispārējās starptautiskās tiesības tad, kad tā darbojas saskaṇā gan ar ANO Statūtu VI, gan arī VII nodaḷu.

3. ANO Drošības padomei ir saistošs pienākums ievērot ANO Statūtus un starptautiskās tiesības, kad vien tā pilda savu funkciju attiecībā uz starptautiskā miera un drošibas uzturēšanu.

4. ANO Drošības padomes darbība saskaṇā ar starptautiskajām tiesībām ir nostiprināta organizācijas mērḳos un netieši ietverta pašā organizācijas pastāvēšanā.

5. Ar ANO dalībvalstu pilnvaru delegéěšanu, pamatojoties uz ANO Statūtiem, ANO Drošības padomei ir pienākums ievērot ANO dalībvalstu pienākumu ievērot ANO Statūtus un starptautiskās tiesības, it īpaši jus cogens normas.

6. ANO Statūtu 24. panta otrajā daḷā, kas noteic, ka ANO Drošības padomei, pildot pienākumu uzturēt starptautisko mieru un drošību, ir jādarbojas saskaņā ar ANO mērḳiem un principiem, ir pamats atzinumam, ka politiskajam orgānam ir saistošas starptautiskās tiesības.

21 ANO ST 27.02.1998. spriedums lietā Questions of Interpretation and Application of the 1971 Montreal Convention arising from the Aerial Incident at Lockerbie (Libyan Arab Jamahiriya v. United Kingdom; Libyan Arab Jamahiriya v. United States of America). 